\title{
Adoption of Recommended Potato Production Practices in Farrukhabad District (U.P.), India
}

\author{
Amit Kumar Mishra ${ }^{\text {* }}$, R. K. Dohrey ${ }^{2}$, Ravindra Kr Pandey ${ }^{3}$, Roop Kumar ${ }^{1}$, \\ Kshitij Parmar ${ }^{1}$ and R. K. Singh ${ }^{3}$
}

${ }^{1}$ Department Agricultural Extension, SVBPUA \& T Modipuram, Meerut (250110), India

${ }^{2}$ Department Extension Education, NDUA \& T Kumarganj, Faizabad (224229), India

${ }^{3}$ Extension Education, NDUA \& T Kumarganj, Faizabad (224229), India

*Corresponding author

\begin{tabular}{|c|c|}
\hline & A B S T R A C T \\
\hline & \multirow{6}{*}{$\begin{array}{l}\text { The present study was carried out during the year } 2013-14 \text { in Farrukhabad } \\
\text { district of central Uttar Pradesh. Total } 100 \text { respondents from these } 5 \\
\text { villages were selected by using proporsnate random sampling technique } \\
\text { and data were collected by means of personal interview. The study revealed } \\
\text { that overwhelming majority ( } 69.00 \text { per cent) of potato grower's had } \\
\text { medium of adoption of potato production technology. The study further } \\
\text { indicates that land holding, annual income, irrigation facilities, extension } \\
\text { participation, social participation, extension contact, scientific orientation, } \\
\text { risk orientation and knowledge had positive and highly significant } \\
\text { correlation with potato growers. While the variables like education, } \\
\text { experience and economic motivation had positive and significant } \\
\text { correlation of the potato growers. }\end{array}$} \\
\hline Keywords & \\
\hline $\begin{array}{l}\text { Potato growers, } \\
\text { Adoption and } \\
\text { Co-relation }\end{array}$ & \\
\hline Article Info & \\
\hline $\begin{array}{l}\text { Accepted: } \\
\text { 25 May } 2017 \\
\text { Available Online: } \\
\text { 10 June } 2017\end{array}$ & \\
\hline & \\
\hline
\end{tabular}

\section{Introduction}

Potato (Solanum tuberosum L.) is one of the major vegetable crops of the world. It is an important crop grown in winter season in plains of India its productivity varies considerably between the regions, between the area within a region and with the cultured practices even at high fertility level. Among the food crops, it ranks fourth in important next only to rice, wheat and corn covering about 21.22 million hectare and fifth in production yielding about 309.5 million tones after sugarcane, rice and maize. The original home of Potato is Andean plateau of South
America. Potato is a most useful and important member of the family solanacea and it belong to genus Solanum, consist of seven cultivated and about 154 wild species but the commercially valuable potato has only two species i.e. Solanum andignum and Solanum tuberosum. It has special value as food apart from starch which is rich source; it also provides

Essential body building substance such as vitamins, minerals and protein. Thus potato is one of the richest sources of calories needed 
to maintain day to day output of human energy per $200 \mathrm{gm}$. of edible portion of potato contain $22.6 \mathrm{gm}$. carbohydrate, $1.6 \mathrm{gm}$. Protein, 10 gm. calcium, 20 gm. magnesium, $247 \mathrm{gm}$. potassium, $17 \mathrm{gm}$. vitamin and 1.2 gm. nicotinic acid. It provides $87 \mathrm{gm}$. calories to human body. Potato can be cooked in many ways; they can be boiled, fried, roasted, baked or steamed, they can also be possessed into flakes, cubes, granules, chips, pan cakes etc. They are good for breakfast, lunch and dinner. Keeping in view the above facts, it was aimed to study the socio economic status of the Potato growers in Farrukhabad district of U.P.

\section{Materials and Methods}

This study was conducted in Farrukhbad district during the year 2013-14. Farrukhbad district comprise of 7 blocks in which one blocks namely Kayamganj were purposively selected. Five villages from Kayamganj blocks were purposively selected and 100 potato growers were selected from all villages. Thus the total sample size was of 100 respondents. The data were collected through personal interview with the help of pre structured schedule. The data were analyzed and find out the percentage and rank order.

\section{Results and Discussion}

The adoption process is the mental process through which an individual passes from first hearing of an innovation to its final adoption, while adoption is a decision to continue the full use of an innovation. Generally, the farmers do not adopt package of practices fully. There is only a partial adoption by them. As a result, the gap always appears between the recommended production technology and their use at farmer's field. With a view to find out the extent of adoption of recommended practices of potato cultivation, the potato growers were asked to give information about package of practices adopted by them. The data regarding extent of adoption are given in Table 1 .

It is clear from Table 1 . That majority of the potato growers (69.00 per cent) had medium level of adoption, followed by high (23.00 per cent) and low (8.00 per cent). It revealed that great majority (69.00 per cent) of potato growers in study area had medium to high level of adoption of recommended production technology of potato.

Practice wise adoption of recommended potato production technology by potato growers: With a view to find out the practice wise adoption of recommended practices of potato cultivation, the potato growers were asked to give information about package of practices adopted by them. The data regarding this are given in Table. Data in Table 2 shows that among the different recommended potato production technologies followed by Seed rate (75.00 per cent), Sowing time (65.00 per cent), Field preparation (64.00 per cent), Amount of manures and fertilizers (53.00 per cent), Improved varieties (50.00 per cent), Time of application of manures and fertilizers (47.00), Irrigation (43.00 per cent), Inter cultural operations (40.00 per cent), Harvest and post-harvest technology (38.00 per cent), Plant protection measures (37.00 per cent), Spacing (31.00 per cent) and Seed treatment (21.00 per cent. Higher level of adoption due to good farming experience, medium to high literacy level and potato crop has been cultivated by majority of farmers in farrukhbad district for many years. Lower level of adoption might be due to poor knowledge about some practices, unsuitability of technology in their own situation, higher cost and complexity of technology.

It is evident from the Table. 1 that Maximum numbers of respondent $(30 \%)$ were reported that they did adopt normal sowing varieties. 
The rest of respondents were reported using late sowing varieties (15\%) and early sowing varieties $(5 \%)$. Therefore, it is is said that the farmers of this area rarely use the improved varieties of potato.

The Table. 2 indicates the position of field prepration by the respodents. First ploughings time of potato observed $(40 \%)$ and before sowing of potato seed, how many plounging (24\%) respectively. Hence it may be aid that field prepration many potato grower adopt.

It is evident from the Table. 3 that Maximum numbers of respondent $(50 \%)$ were reported that they did adopt for normal sowing. The rest of respondents were reported using for late sowing $(15 \%)$ and for early sowing therefore, it is said that the farmers of this area rarely use scientific seed rate of potato.

The data presented Table.4 that maximum number of respondents $(15 \%)$ reported that their adopt hormone for seed treatment and how much are followed by (5\%) and respondents adopted how many hour before sowing, treated the seed with hormone (1\%) respondents respectively.

It is evdent from the Table.5 that Maximum number of respondent $(30 \%)$ were reported that they din adopt for normal sowing. The rest of respondents were reported using for late sowing $(255 \%)$ and for early sowing $(10 \%)$. Therefore, it is said that the farmers of this area rarely use scientific time of sowing of potato.

Table.1 Distribution of the respondent according to overall adoption

\begin{tabular}{|c|c|c|c|}
\hline S.No. & Categories (age) & $\begin{array}{c}\text { Number of } \\
\text { respondent }\end{array}$ & Percent \\
\hline $\mathbf{1 .}$ & Low (up to 8) & 8 & 8.00 \\
\hline $\mathbf{2 .}$ & Medium (9-16) & 69 & 69.00 \\
\hline $\mathbf{3 .}$ & High (17-24) & 23 & 23.00 \\
\hline & Total & $\mathbf{1 0 0}$ & $\mathbf{1 0 0 . 0 0}$ \\
\hline
\end{tabular}

Table. 2 Practice wise adoption of recommended potato production technology by potato growers

\begin{tabular}{|l|l|c|c|}
\hline S.No. & \multicolumn{1}{|c|}{ Practices } & $\begin{array}{c}\text { Number of } \\
\text { respondents }\end{array}$ & Percentage \\
\hline 1. & Field preparation & 64 & 64.00 \\
\hline 2. & Seed rate & 75 & 75.00 \\
\hline 3. & $\begin{array}{l}\text { Time of application of manures and } \\
\text { fertilizers }\end{array}$ & 47 & 47.00 \\
\hline 4. & Harvest and post-harvest technology & 38 & 38.00 \\
\hline $\mathbf{5 .}$ & Sowing time & 65 & 65.00 \\
\hline $\mathbf{6 .}$ & Irrigation & 43 & 43.00 \\
\hline $\mathbf{7 .}$ & Spacing & 31 & 31.00 \\
\hline $\mathbf{8 .}$ & Amount of manures and fertilizers & 43 & 53.00 \\
\hline $\mathbf{9 .}$ & Inter cultural operations & 40 & 40.00 \\
\hline $\mathbf{1 0 .}$ & Seed treatment & 21 & 21.00 \\
\hline $\mathbf{1 1 .}$ & Improved varieties & 50 & 50.00 \\
\hline $\mathbf{1 2 .}$ & Plant protection measures & 37 & 37.00 \\
\hline
\end{tabular}


Table.3 Distribution of respondents according to adoption extent

About improved varieties Potato

\begin{tabular}{|l|l|l|l|}
\hline S.No. & Categories & \multicolumn{2}{l|}{ Respondents } \\
\cline { 3 - 4 } & & No. & Percentage \\
\hline $\mathbf{1 .}$ & Early sowing varieties & 05 & 5.00 \\
\hline $\mathbf{2 .}$ & Normal sowing varieties & 30 & 30.00 \\
\hline $\mathbf{3 .}$ & Late sowing varieties & 15 & 15.00 \\
\hline Total & $\mathbf{5 0}$ & $\mathbf{5 0 . 0 0}$ \\
\hline
\end{tabular}

Table.4 Distribution of respondents according to adoption extent of field preparation

\begin{tabular}{|l|l|l|l|}
\hline S.No. & Categories & Respondents \\
\cline { 3 - 4 } & & No. & Percentage \\
\hline 1. & When did you plough your potato field first & 40 & 40.00 \\
\hline 2. & $\begin{array}{l}\text { Before sowing of potato seed, how many } \\
\text { ploughings did you do }\end{array}$ & 24 & 24.00 \\
\hline \\
Total & $\mathbf{6 4}$ & $\mathbf{6 4 . 0 0}$ \\
\hline
\end{tabular}

Table.5 Distribution of respondents according to adoption extent of seed rate

\begin{tabular}{|l|l|l|l|}
\hline S.No. & Categories & Respondents \\
\cline { 3 - 4 } & & No. & Percentage \\
\hline $\mathbf{1 .}$ & For early sowing & 10 & 18.00 \\
\hline $\mathbf{2 .}$ & For normal sowing & 50 & 48.00 \\
\hline 3. & For late sowing & 15 & 34.00 \\
\hline Total & $\mathbf{7 5}$ & $\mathbf{7 5 . 0 0}$ \\
\hline
\end{tabular}

Table.6 Distribution of respondents according to adoption extent of seed treatment

\begin{tabular}{|l|l|c|c|}
\hline S.No. & \multicolumn{1}{|c|}{ Categories } & \multicolumn{2}{|c|}{ Respondents } \\
\cline { 3 - 4 } & & No. & Percentage \\
\hline 1. & $\begin{array}{l}\text { Which fungicide did you apply to treat the potato } \\
\text { seed? }\end{array}$ & 15 & 15.00 \\
\hline $\mathbf{2 .}$ & $\begin{array}{l}\text { How much Fungicide did you use to treat one kg } \\
\text { of seed? }\end{array}$ & 05 & 5.00 \\
\hline 3. & $\begin{array}{l}\text { For how many hours before sowing, you treated } \\
\text { the seed with fungicide? }\end{array}$ & 01 & 1.00 \\
\hline
\end{tabular}

Table.7 Distribution of respondents according to adoption extent of time of sowing

\begin{tabular}{|l|l|c|c|}
\hline \multirow{2}{*}{ S.No. } & \multicolumn{1}{c|}{ Categories } & \multicolumn{2}{c|}{ Respondents } \\
\cline { 3 - 4 } & & No. & Percentage \\
\hline 1. & Early sowing & 10 & 10.00 \\
\hline 2. & Normal sowing & 30 & 30.00 \\
\hline 3. & Late sowing & 25 & 25.00 \\
\hline Total & $\mathbf{6 5}$ & $\mathbf{6 5 . 0 0}$ \\
\hline
\end{tabular}


Table.8 Distribution of respondents according to adoption extent of spacing

\begin{tabular}{|l|l|c|c|}
\hline \multirow{2}{*}{ S.No. } & \multicolumn{1}{|c|}{ Categories } & \multicolumn{2}{|c|}{ Respondents } \\
\cline { 3 - 4 } & & No. & Percentage \\
\hline 1. & Row to row & 15 & 15.00 \\
\hline 2. & Plant to plant & 03 & 3.00 \\
\hline 3. & Depth & 13 & 13.00 \\
\hline Total & $\mathbf{3 1}$ & $\mathbf{3 1 . 0 0}$ \\
\hline
\end{tabular}

Table.9 Distribution of respondents according to adoption extent of manures and fertilizers

\begin{tabular}{|l|l|c|c|}
\multicolumn{2}{|c|}{ Categories } & \multicolumn{2}{c|}{ Respondents } \\
\cline { 3 - 4 } & & No. & Percentage \\
\hline 1. & Manures are applied which and how much & 10 & 10.00 \\
\hline 2. & Fertilizers are applied which and how much & 30 & 30.00 \\
\hline \multicolumn{2}{|c|}{ Total } & $\mathbf{4 3}$ & $\mathbf{4 3 . 0 0}$ \\
\hline
\end{tabular}

Table.10 Distribution of respondents according to adoption extent of

Time of application of manures and fertilizers

$\mathrm{N}=100$

\begin{tabular}{|l|l|c|c|}
\hline S.No. & Categories & \multicolumn{2}{|c|}{ Respondents } \\
\cline { 3 - 4 } & & No. & Percentage \\
\hline 1. & FYM \& Compost & 10 & 10.00 \\
\hline 2. & NPK \& Sulphur & 37 & 37.00 \\
\hline \multicolumn{2}{r|}{ Total } & $\mathbf{4 7}$ & $\mathbf{4 7 . 0 0}$ \\
\hline
\end{tabular}

Table.11 Distribution of respondents according to adoption extent of irrigation

Table.12 Distribution of respondents according to extent of intercultural operations

\begin{tabular}{|l|l|c|c|}
\hline \multirow{2}{*}{ S.No. } & \multicolumn{2}{|c|}{ Categories } & \multicolumn{2}{|c|}{ Respondents } \\
\cline { 3 - 4 } & & No. & Percentage \\
\hline 1. & Basalin & 20 & 20.00 \\
\hline 2. & Metribusin & 10 & 10.00 \\
\hline 3. & Pendimethyl & 10 & 10.00 \\
\hline \multicolumn{2}{|c|}{ Total } & 40 & 40.00 \\
\hline
\end{tabular}


Table.13 Distribution of respondents according to extent of plant protection measures

\begin{tabular}{|l|l|c|c|}
\hline \multicolumn{1}{|c|}{ Categories } & \multicolumn{2}{c|}{ Respondents } \\
\cline { 3 - 4 } & & No. & Percentage \\
\hline 1. & Actara and Plenum & 07 & 7.00 \\
\hline 2. & Monocrotofash 35Ec & 20 & 20.00 \\
\hline 3. & Aqequate & 10 & 10.00 \\
\hline \multicolumn{2}{|c|}{ Total } & 37 & 37.00 \\
\hline
\end{tabular}

Table.14 Distribution of respondents according to adoption extent of Harvest and post-harvest technology

\begin{tabular}{|l|l|c|c|}
\hline \multirow{2}{*}{ S.No. } & Categories & \multicolumn{2}{|c|}{ Respondents } \\
\cline { 3 - 4 } & & No. & Percentage \\
\hline 1. & Early maturity & 05 & 5.00 \\
\hline 2. & Normal maturity & 20 & 20.00 \\
\hline 3. & Late maturity & 10 & 10.00 \\
\hline \multicolumn{2}{|c|}{ Total } & 35 & 35.00 \\
\hline
\end{tabular}

$\mathrm{N}=100$

Table.15 Relationship between the characteristics of potato growers and their level adoption of recommended technology of potato crop

\begin{tabular}{|l|l|c|}
\hline S. No. & \multicolumn{1}{|c|}{ Independent Variables } & Correlation coefficient \\
\hline 1. & Age & $-0.43035^{* *}$ \\
\hline $\mathbf{2 .}$ & Education & $0.776637^{* *}$ \\
\hline $\mathbf{3 .}$ & Caste & $0.320652^{* *}$ \\
\hline $\mathbf{4 .}$ & Family type & 0.084515 \\
\hline $\mathbf{5 .}$ & Family size & 0.055022 \\
\hline $\mathbf{6 .}$ & Housing pattern & $0.204595^{*}$ \\
\hline $\mathbf{7 .}$ & Land holding & 0.087431 \\
\hline $\mathbf{8 .}$ & Occupation & $0.197532^{*}$ \\
\hline $\mathbf{9 .}$ & Annual income & $0.247021^{*}$ \\
\hline $\mathbf{1 0 .}$ & Material possession & $0.288649 * *$ \\
\hline 11. & Social participation & 0.129953 \\
\hline 12. & Extent of contact with information sources & 0.163852 \\
\hline 13. & Scientific orientation & 0.138498 \\
\hline 14. & Economic motivation & 0.176527 \\
\hline 15. & Risk orientation & -0.061 \\
\hline
\end{tabular}

$*$ Significant at $0.05 \%$ probability level $0.197, * *$ Significant at $0.01 \%$ probability level 0.257 
Fig.1 Respondent according to overall adoption

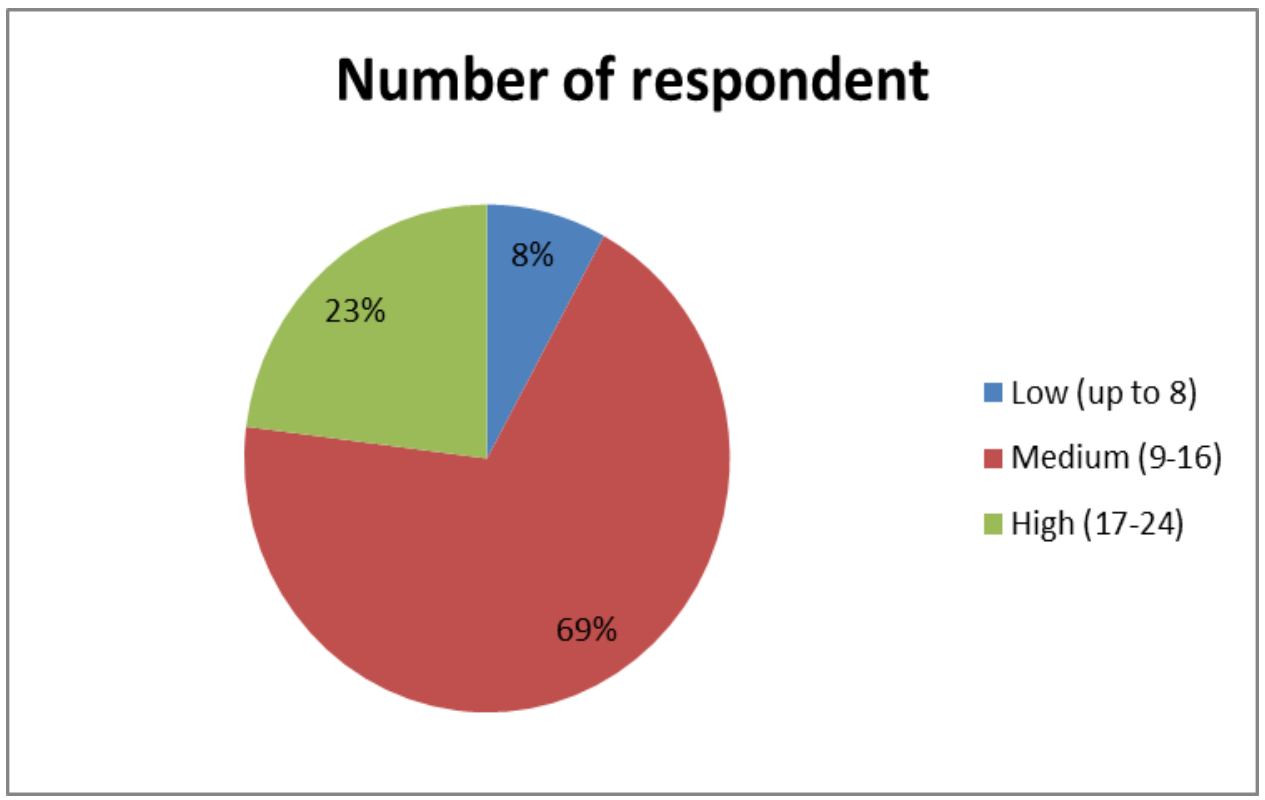

Fig.2 Practice wise adoption of recommended potato production technology by potato growers

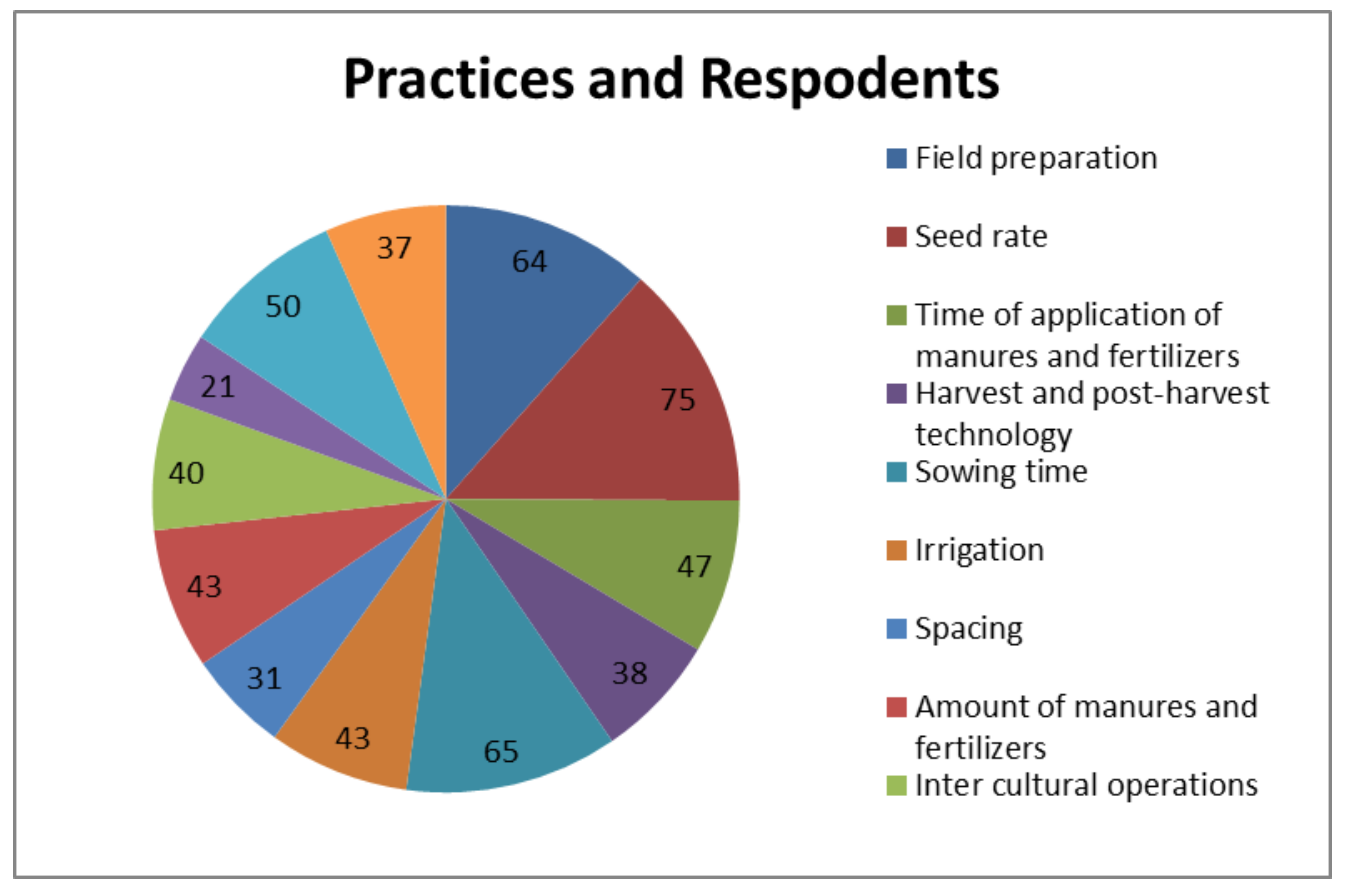

It is evdent from the Table. 6 that Maximum number of respondent $(15 \%)$ were reported that they din adopt for Row to row spacing. The rest of respondents were reported using for depth $(13 \%)$ and for plant to plant spacing $(3 \%)$. Therefore, it is said that the farmers of this area rarely use scientific spacing of potato.

The data presented Table.7 that maximum number of respondents $(30 \%)$ reported that adopt their scientific fertilizer quantity and 
scientific manures quantity are followed by (13\%) respondents respectively.

The data presented Table. 8 that maximum number of respondents $(37 \%)$ their adopt NPK \& Compost and adopted FYM \& Compost, time of application of manures and fertilizers $(10 \%)$ respondents respectively.

It is obvious from the Table.9 over whiling majority $(23 \%)$ of the respondents was adopting the timely irrigation and (20\%) respondents timely give critical stage irrigation.

The Table.10 shows that the adopt extent of intercultural operation. On an average the maximum number of respondents $(20 \%)$ were adopt the Basalin and (10\%) respondents Metribusin and pendimethyl are equally.

The Table.11 shows that the adopt extent of plant protection. On an average the maximum number of respondents $(20 \%)$ were adopt the Monocrotofash, (10\%) and (7\%) respondent's view of Aqequate and Actara and Plenum, respectively.

It is evident from the Table.12 that Maximum number of respondent $(20 \%)$ were adopted that they din adopt normal maturity. The rest of respondents were reported using late maturity (10\%) and early maturity (5\%). Therefore, it is is said that the farmers of this area rarely use the harvest and post-harvest technology of potato.

The data with regard to relationship of independent variable with adoption are presented in Table 15 reflect that the independent variables like Age, education, caste and Material possession, had positive and highly significant correlation with adoption of potato growers. While the variables like Annual income, occupation and Housing pattern had positive and significant correlation with adoption of the potato growers. While the variables like Family type, Family size, Land holding, Social participation, Extent of contact with information sources, Scientific orientation and Economic motivation showed positive and non-significant and Risk orientation showed non- significant correlation with adoption of recommended production technology of potato.

In conclusion, the study revealed that majority of the potato growers belonged to medium level of adoption. Most of potato growers were found in non-adaptor category in respect of certain important items like Seed rate, Sowing time and Field preparation. All the selected attributes of the potato grower's except age, education and caste showed positive and significant correlation with their adoption level. So as to enhance adoption level, it is necessary to involve the farmers in extension education programme. It would facilitate the dissemination of recent Practices.

\section{Acknowledgement}

Author is thankful to Dr. R.K. Dohrey, Professor and Head, Department of Extension Education, NDUA\&T Kumarganj, Faizabad 224229 (U.P.) India for his kind guidance, motivation and unconditional support for this work.

\section{References}

Peer, Q. J. A; Satesh Kumar Aziz, M. A; Jasvinder Kaur Chesti, M. H. and Anil Bhat (2014). Adoption behaviour of potato growers in sub-tropical zone of Jammu division. African Journal of Agricultural Research, 9(2):202-205.

Pandit, Arun. Rana, K. Anil. Pandey, R. K. K, N. and Kumar, N. R. (2010). A study on socio-economic profile of potato 
farmers: comparison of irrigated and rainfed conditions in Himachal Pradesh. Tropical Agricultural Research and Extension; 41(8):69-74

Khalil, M. I; Haque, M. E. and Hoque, M. Z. (2013). Adoption of BARI recommended potato (Solanum tuberosum) varieties by the potato farmers of Bangladesh. The Agriculturists, 11(2):79-86.

Namwata, B. M. L; Lwelamira, J. and Mzirai, O. B. (2010). Adoption of improved agricultural technologies for Irish potatoes (Solanum tuberosum) among farmers in Mbeya Rural district, Tanzania: a case of Ilungu ward. Journal of Animal and Plant Sciences (JAPS); 8(1):927-935. 30

Madhuprasad, V. L; Kumar, G. V. M; Venkataramana, P. and Muniswamappa, M. V. (2002). Survey on adoption of potato storage practices in Kolar District.Current Research - University of Agricultural Sciences (Bangalore); 31(5/6):91-93

\section{How to cite this article:}

Amit Kumar Mishra, R. K. Dohrey, Ravindra Kr Pandey, Roop Kumar, Kshitij Parmar and Singh R. K.. 2017. Adoption of Recommended Potato Production Practices in Farrukhabad District (U.P.), India. Int.J.Curr.Microbiol.App.Sci. 6(6): 3319-3327. doi: http://doi.org/10.20546/ijcmas.2017.606.390 